\title{
Ghana's Evolutionary Role in a Changing World Economic Order
}

\author{
Joel Osarcar Barima \\ London College of Management Studies, Brent House, 214 Kenton Road, \\ Harrow, Middlesex, HA3 8BT. \\ Email:joel@londoncms.com
}

\begin{abstract}
The world economy has been passing through interesting and significant changes for several years now promising for some (the emerging countries in particular) and not so promising for others (the developed countries). Huge transfer of resources has taken place and the process is continuing. In this context, it is but natural for African observers to raise the question: African share of world resources remaining somewhat unchanged (as per the World Bank data), what is the role and future of the African countries in this changing scenario? Are they going to be partners in the transfer of resources that is being experienced? An attempt has been made here to examine the case of Ghana - a leading economy in the continent. The author would contend that although the country is poised to grow spectacularly as some forecasters would envisage, thanks to the prospect of oil revenues, Ghana has to traverse a long way if it is to be noticed in the world bodies. Growth and development must occur in substantive measures from the present state of affairs. Agriculture, almost the backbone for any developing country, must take the lead to offer meaningful support to the more promising industry. The real economy, in its basic form, must be properly understood, developed and managed with strategic investments in place. And this must be followed by or accompanied with a vibrant knowledge-based service economy. Failing this, the burgeoning oil wealth may only be hallucinatory at best.
\end{abstract}

Keywords: Ghanaian economy; World economic order; Economic forecast

\section{Introduction}

The world economy grew $5.2 \%$ in 2007 powered by growth in China (11\%), India (9\%) and Russia (8\%) and Brazil (6.1\%). The Emerging Markets, led by the giants of China, India, Russia and Brazil (the BRIC countries) had been posting 7\%-10\% growth rates for years. Property and stock market booms had brought consistent growth in North America and Europe. Investment in various parts of the world were enhanced both by FDI and governments' intervention, particularly in developing countries where governments have been the major players in investments. These investment programs brought economic development to much of the Middle East and Africa, and even Japan was recovering from its deflationary 'Lost Years'.

In spite of the early boom of the millennium, the world was suddenly faced with economic downturn at the end of 2007 and early 2008. The global financial service giant Lehman Brothers Inc. filed for liquidation after huge losses in the mortgage market and a loss of investor confidence crippled it, and it was unable to find a buyer. The fall of Lehman Brothers was closely followed by the near collapse of the Northern Ireland Bank in the UK. It took the intervention of a bailout package by the UK government (tax payer) to save NIB from collapsing.

These happenings in the world economy as a whole have had a telling effect on the business environment, making it more challenging than ever before. National governments, who fail to run their economies like business entities are finding it increasingly difficult to cope with the present economic order. The present world order, calls for measures and strategies by national governments to reduce the negative impact of the economy downturn on the citizenry. Failure to act swiftly is sending some nations to near bankruptcy, as has recently been witness in Greece and Ireland.

Developed economies responded to the downturn by providing economic stimulus to stimulate growth, reduce unemployment, tax cuts, and loans to SME and improve total productivity. Among other things in the US, the purpose of the economic stimulus package was also to prevent the reemergence of the panic that gripped investors in 2008. It was also aimed to restore trust in the finance 
industry by further limiting bonuses for senior executives for companies that received TARP funds (CBO, 2009). The US Congress voted for a total of $\$ 787$ billion; aimed at jumpstarting economic growth and saving 900,000 to 2.3 million jobs (US economy.com)

In the UK $\$ 30$ billion stimulus package was announced in November 2008 (The Washington Post, 2008). The aim was to offer financial relief to most Britons by cutting the sales tax from 17.5 percent to 15 percent while increasing the top marginal tax rate from 40 percent to 45 percent - for the country's richest 1 percent. The UK's package was also aimed at increasing expenditure in the public sector to boost employment, extend loans to small to medium enterprises and to grow the economy as a whole. The UK's proposal found favor with the rest of their European counterparts.

A German economic stimulus package of $€ 50$ billion, ( $\$ 66.8$ billion) was also instituted in 2008 . This economic stimulus package for Germany was spread over a period of two years. This economic stimulus package to Germany; very broadly includes infrastructural investments, social benefits, tax concessions and soft loans. A substantial portion of this German economic stimulus package, of about $€ 17-18$ billion, was in the form of investments to be made in highway construction, educational spending, and tax cuts for individuals and businesses. The German government also allocated $€ 100$ billion towards loan for sick and recovering industries. These credit and guarantee funds were to inspire upgrading of old manufacturing processes with updated technologies (Economic Watch, 2008).

Even though, these economic measures were designed to put these economies out of the economic recession and onto the path of growth, very little has been achieved (if any) by way of economic growth. The GDP figures for these major economies since the economic stimulus packages were introduced have not seen significant improvements. In the US the funds were projected to increase growth by $1.4-3.8 \%$. This however did not mean that GDP growth was positive. The economy remained in recession according to the Washington Post, 2008. The UK economy only grew by $0.3 \%$ in the last quarter of 2009. However, the size of the overall contraction in gross domestic product (GDP) during the recession increased, from $6 \%$ fall to $6.25 \%$ drop (BBC News, 2010). As of the end of 2010, the whole economy grew by $0.2 \%$ even after the various economic programs devised to grow the economy.

The Germany story is not different, as of the middle of 2009 the GDP had dropped to $5.6 \%$ and only managed to achieve $3.9 \%$ growth rate at the end of 2010. The impact of the various packages has not given the desired growth. This can be attributed to the fact that these stimulus packages were introduced at the time these economies had been deeply caught in the recession. Unemployment in the US for example stands at $9.3 \%$, making it the 110 th ranking in world and UK at $7.9 \%$ and ranked at 84 th (CIA 2011). The present robust economy order, currently being experienced in the world has not made the economic response as effective as expected. This has necessitated other measures to be adopted as possible solutions to improve economic growth both in the short and long term. For example in the UK, government is responding by cutting government expenditure in the public sector, increase value added Tax (VAT) to 20\% unprecedented in the history of the VAT service and is focusing on reducing the total national debt. The US is also responding by encourage and instituting conditions favourable for foreign direct investment (FDI). These measures are still on-going and some have just been implemented hence the efficacy of the interventions is yet to be known.

Following the economic recession and the various interventions instituted by major economies, developing countries particularly, the Asians and Africans seem to be quickly growing their economies at a fast rate than their advanced economic counterparts. Table 1 shows that Qatar for example, had a growth rate of $16.4 \%$ in 2010 .

Table 1

National growth rate

\begin{tabular}{llr}
\hline Position & Country & Growth Rate \\
\hline 1. & Qatar & $16.4 \%$ \\
2. & Botswana & $14.4 \%$ \\
3. & Azerbaijan & $12.3 \%$ \\
4. & Republic of Congo & $11.9 \%$ \\
5. & Angola & $9.3 \%$ \\
6. & East Timor & $7.87 \%$ \\
7. & Liberia & $7.53 \%$ \\
8. & China & $7.51 \%$ \\
9. & Afghanistan & $7.01 \%$ \\
10. & Uzbekistan & $7.00 \%$ \\
11. & Turkmenistan & $6.96 \%$ \\
12. & Iraq & $6.69 \%$ \\
\hline
\end{tabular}

Source: GDP Growth forecast 2010: Economic watch.com economic statistics database 
With the exception of China, none of the countries in the G20 made the top 12 to grow its economy significantly in 2010. Even though China is perceived to be the fastest growing economy by many academicians and social commentators, which is true when viewed from the largest economies. However in terms of the total global economic growth China placed 8 in 2010 and is forecast to rise to fourth in 2011 above Liberia (Economic Watch). Again, the focus of economic growth as indicated by data from the Economic Watch support the assertion that economic growth in the world is shifting from developed economies to developing worlds with African, the Middle East and Asian countries playing leading roles. As shown in Table 2, in 2010, four African countries made the list of the first 12 countries whose economies showed significant growth following the recession that was experienced in the later part of the decade.

Table 2

National GDP growth forecast 2011.

\begin{tabular}{|c|c|c|c|}
\hline Position & Country & Forcast & Grow Rate \\
\hline 1 & Ghana & & $20.146 \%$ \\
\hline 2 & Qatar & & $14.337 \%$ \\
\hline 3 & Turkmenistan & & $12.178 \%$ \\
\hline 4 & China & & $9.908 \%$ \\
\hline 5 & Liberia & & $9.003 \%$ \\
\hline 6 & India & & $8.430 \%$ \\
\hline 7 & Angola & & $8.251 \%$ \\
\hline 8 & Iraq & & $7.873 \%$ \\
\hline 9 & Ethiopia & & $7.663 \%$ \\
\hline 10 & Mozambique & & $7.548 \%$ \\
\hline 11 & Timor Leste (East Timor) & & $7.400 \%$ \\
\hline 12 & Laos & & $7.395 \%$ \\
\hline
\end{tabular}

Source: Economic Watch, 2010

In 2011, the number of African countries predicted to grow their economies in the world list of 12 countries had risen to five, with Ghana topping the list (Economic Watch, 2010).

The data show that Ghana will lead the world in terms of GDP growth in the year ahead. Ghana has since the last two decades embraced democratic governance, which has put the nation out of the perennial military interventions. The country has successfully changed its governments through the ballot box, making successive governments more accountable to the electorate. The stable governance front has allowed governments to concentrate efforts on improving the living conditions of the citizenry.
Management of the national economy has become the main yardstick upon which governments and political parties are assessed. The pressure from the populace, the media and social commentators for good management of the economy by governments looks to be yielding dividends as shown by the growth predictions of the Economic Watch.

Whether these favourable predictions, coupled with the Ghanaian pressure on their governments, would make Ghana assume a leading role in growing her economy in the coming year and into the future is a field that requires researching into. In measuring economic growth in Ghana, three areas of the Ghanaian economy would be carefully studied to evaluate how these areas have contributed to the GDP growth and whether it is sustainable in the long run. The Service Sector, Agricultural Sector and the Industrial Sector data trends would be review to ascertain their contribution to the Gross Domestic Product. The economic data from these sectors of the Ghanaian economy would be compared with other Advanced economies to establish the areas of emphasis and suggest strategies for sustainable growth. The research should provide a road map for successive governance programs in the country both to Political Parties and Governments. It will also aim to provide a tool for investors both in the private sector and foreign investors in the Ghanaian economy. The research will employ both qualitative and quantitative data in its analysis.

\section{Factors affecting gross domestic product (GDP)}

The GDP of a country is the total goods and services provided in a given year. This shows the contribution of the various sectors of the economy to the total income of the country in a fiscal year. The gross value does not take into consideration the total expenditure of the nation. If the expenditure is deducted, then what is obtained is the real GDP. The upward or downward movement of the GDP value within the fiscal year determines whether or not there has been any economy growth. If the GDP value drops, it is described as economic downturn.

There are three different theoretical approaches used in the estimation of GDP.GDP from the output or production approach-GDP $(\mathrm{O})$ measures the sum of the value added created through the production of goods and services within the economy (production or output as an economy). This approach provides the first estimate of GDP and can be used to show how much different sectors contribute within the 
economy. GDP (I) measures the total income generated by the production of goods and services within the economy. The figures provided break down this income into, for example, income earned by companies (corporations), employees the selfemployed. GDP from the expenditure approach GDP (E) measures the total expenditures on all finished goods and services produced within the economy. The estimates are 'Gross' because the value of the capital assets actually worn away (the 'capital consumption') during the productive process has not been subtracted.

There are two methods of GDP calculation: nominal GDP attempts to compare countries using current exchange rates to give an assessment of their clout within the global market. Purchasing Power Parity or PPP GDP, on the other hand, tries to take into account that one dollar can buy more in some countries and less in others. It is a better gauge of the internal size of each market. Theoretical GDP is determined by the aggregate contribution of Households, Governments and industry. However, in recent years, development economists have relied heavily on cross-country data to study the process and determinants of economic growth. Two key assumptions lie at the core of many of these studies.

First, there is a ceiling on the level of income per worker that a country can attain. This ceiling, which is usually denoted as the country's steady-state level of income, depends on the country's characteristics, such as the extent of its natural resource base, the level of education of its population, the quality of its institutions, the features of its physical geography, and the nature of its economic policies. Because these characteristics vary across countries, so too will the levels of income they can attain. Second, development economists assume that the difference between a country's potential income and actual income is reduced every time period by a constant fraction (Bloom, Canning and Malaney, 1999).

This model of economic growth has two powerful implications. First, it implies that the poorer a country is with respect to its steady state, the faster it is likely to grow. This is sometimes referred to as the income catch-up phenomenon. Second, the higher a country's ceiling level of income, the faster its expected rate of growth for a given level of initial income. This has been dubbed "conditional convergence". Although this model is developed in terms of income per worker, it is generally tested using data on income per capita, development economists' standard measure of economic performance. Because the model is estimated using growth rates, as opposed to levels of income, distinguishing between income per person of working age and income per capita makes no difference in stable populations (for which the growth rate of the overall population is equal to that of the working-age population).

\section{Financial system and economic growth}

A sound financial system of the country plays an important role in the determining the economic growth. According to Rousseau and Sylla (2001), a good financial system is one that has five key components. These components are (1) sound public finances and public debt management, (2) a variety of banks, some with domestic and others with international orientations, and perhaps some with both orientations, (3) a central bank to stabilize domestic finances and manage international financial relations, and (4) well-functioning securities markets. Such an articulated financial system, once it is in place and functioning, can mobilize capital domestically and thereby promote a country's economic development and growth. (5) stable monetary Insurance might well be added to our list, as a fifth component. We leave it out here, in part because it involves a function risk management similar to that in which another component, banking, engages, and in part because, in a global historical context, it could be and often was supplied by insurers in other countries.

In a financial globalization context, it can also serve, either directly by the facilities it offers or indirectly by enhancing growth prospects, to attract the interest of foreign investors. First, academic specialization being what it is, contemporary scholars and those of previous generations often focus their attention on one or a subset of the components. Some economists are public finance experts, while others study money, banking, and central banking. Securities markets and company finance are usually the provinces of finance departments in business schools. Even economic historians, who often take a longer and broader view of economic development than economists and finance specialists, tend to concentrate on one component-usually banking-or a subset of them. Our view is that in a well-functioning financial system, there are numerous interactions among all of our five components. Hence, the authors think that the unit of observation for studying finance role in economic modernization should be the financial system as a whole, and not just one or two of its components. 
Second, whenever one peels back the layers of the great onion of history, stopping at a layer that seems important for later developments, the question inevitably arises. But what made that layer possible? In our case, what makes a good financial system possible? What are its prerequisites? Without going into detail, the authors would say that the prerequisites would likely include a combination of good government, including representative political institutions, an independent judiciary or court system, clearly defined and secure property rights, and financial savvy on the part of leaders finance ministers, central bankers, and so on among the components of a good system. The authors place sound public finance first in our list of financial system components largely for historical reasons. In modern history, good financial systems emerged out of the needs of the nation state for financing, often to fight its wars with other nationstates. Sound public finance includes setting and controlling public expenditure priorities, raising revenues adequate to fund them efficiently, and if--as is often the case-that involves issuing public debt, then provision must be made for servicing the debt to gain and keep the confidence of the investors who purchase it.

\section{Methodology}

The researcher used both primary and secondary data in writing this research paper. Primary data was obtained from governmental agencies, ministries and the Ghana Statistical Department and Industrial Sector operators. The authors also interviewed a cross-section of farmers, private transport operators and traders who uses the service of microfinance schemes. Microfinance operation in Ghana is become the main source of finance for most petty traders and other operators in the economic cycle. Both face-face and telephone interviews were employed in gathering the primary data. Semi-structured questions were asked. The semi- structure nature of the questions allowed the respondent to make inputs as well. It also allowed the researchers to collect the facts that were relevant to the study whilst enabling the participants to express their personal opinions about the general shape of the Ghanaian economy. This was particularly useful in gathering the required information as some respondent depending on their political affiliations gave various views as they perceived the performance of the Ghanaian economy. Since most of the interviewees particularly those in the private transport sector and the farming communities had no formal education or had limitation in their use of the English language, questions had to be translated to the local dialect.

Much of the data gathered was obtained from secondary sources. The secondary sources used included data from the World Bank economic prospect outlook of countries, Statistical offices of Germany, UK, USA and other countries, the Economic Watch and extensive search on the internet. Secondary data was extensively used because the study involved cross-country analysis in helping the researchers make a comparative judgement of the prospects of the Ghanaian economy. The data required for the study was readily available through the secondary source; as such most of the country embassies based in the UK re-directed the researchers to their web database. In order to compare contribution patterns for GDP in regional blocks and that of Ghana. The researcher adopted the "World Bank Development Indicators 1998, republished by Summer and Heston (1991) and Bloom and Canning (1999). Percentage contribution of the Agricultural, Industry and Service sectors to Ghana's GDP were obtained from The Country's Budget statement, the Ghana Statistical Service and the Ministry of Finance and Economy Planning (MoFEP).

\section{Ghana's economic historical trend}

The economic trends in sub-Saharan Africa have not seen much improvement since independence from their respective colonial Masters. Ghana was one of the few countries that had early independence from Britain. The then Ghanaian leader Dr. Nkrumah, who led the country to independence, laid strong emphasis on industrialisation with the establishment of Akosombo hydroelectric power to provide energy for industry. His vision of industrial growth was however curtailed by his over throw in a coup de tat in 1966. The colonial economy then had a dual structure: the co-existence of labor-intensive production techniques with a few capital-intensive manufacturing sectors. The economy of Ghana could best be described as an agrarian one. The agricultural sector has consistently employed 60 to $65 \%$ of the workforce. The sector has been the major contributor to the country's GDP over the years.

Most capital goods and consumer goods imported and exported were dominated by cocoa, which contributes about 60 percent of the foreign exchange earnings. Ghana is endowed with a broad range of natural resources, such as arable land, forest, and sizeable deposits of gold, diamond, bauxite and manganese as well as considerable potential for 
hydroelectric power. The economy has traditionally depended to a high degree on primary (agricultural as well as mineral) production and exports. Exports of cocoa, gold and timber still account for bulk of total merchandise exports. Despite being a country with plenty of natural resources, Ghana is still heavily dependent on international aid and technical assistance. During the 1980s, Ghana's economy registered strong growth of approximately 6 percent per year because of a reversal in the steadily declining production of the previous decade. Ghana's worst years were 1982 and 1983, when the country was hit with the worst drought in fifty years, bush fires that destroyed crops, and the lowest cocoa prices of the postwar period. Growth throughout the remainder of the decade reflected the pace of the economic recovery, but output remained weak in comparison with 1970 production levels. The same was true of consumption, minimum wages, and social services.

Table 3

Ghana's projected growth rate (using the old series method.)

\begin{tabular}{lrrrrrr}
\hline Activity & \multicolumn{3}{c}{$\begin{array}{c}\text { GDP Growth rate(Excluding Oil) } \\
(\%)\end{array}$} & \multicolumn{3}{c}{ Oil GDP Growth Rate (Including Oil) } \\
& \multicolumn{3}{c}{$(\%)$} \\
\hline GDP & 2011 & 2012 & 2013 & 2011 & 2012 & 2013 \\
Agriculture & 7.0 & 7.0 & 7.0 & 12.3 & 9.3 & 8.3 \\
Industry & 6.1 & 6.0 & 6.0 & 6.2 & 6.1 & 6.0 \\
Service & 8.2 & 8.4 & 8.4 & 25.4 & 14.1 & 12.0 \\
\hline
\end{tabular}

Source: Ghana's budgets Statement for 2011.

The on-set of the oil production in the last quarter of 2010 coupled with the associated industries that will spring up in the sector will positively impact on Economic growth. The oil and gas production is further consolidating the effort to ensure accelerated growth according to the Finance Minister. The careful and rigorous re-basing of the national income has revealed that the size of the economy has become bigger.

\section{Regional highlights}

East Asia and Pacific, with GDP growth estimated at $9.3 \%$ for 2010 , led the global recovery. This was on the back of an estimated $10 \%$ increase in Chinese GDP and a 35\% increase in its imports. Output growth in the rest of the region was also strong at $6.8 \%$. Loose monetary policy in highincome countries boosted capital inflows, with the

\section{Overview of Ghana's economic development in relation to the rest of the world}

The global economy has experienced turbulence in recent times and this has propelled national governments to adjust in order to adapt to changes in economic trends. The crisis has not only been a curse, but has also brought along it challenges to the developing world. The developing world has positively embraced the challenge and is growing their economics; for which Asian and African countries particularly Ghana is making great economic impact. Ghana has rebounded from the slowdown in 2009 and has instituted strong macroeconomic fundamentals to position itself to benefit from the global economic recovery. In 2009, the growth rate of 4.1 percent was experienced; this figure has increased to 5.9 above a regional projected growth of 5.5 percent. In the 2011 budget statement, the Finance Minister made the following projections about the economy (see Table 3). 
boom years. Growth is forecast to slow somewhat to around $4 \%$ in 2011 and 2012, largely because of a weaker external environment as growth in advanced economies and China moderates. Several countries in the region have been subject to potentially destabilizing capital inflows that have contributed to strong upward pressure on some currencies.

Table 4

Sectoral structure in developing regions, 1970 to 1990

\begin{tabular}{|c|c|c|c|c|c|c|c|}
\hline $\begin{array}{l}\text { Regional } \\
\text { Blocks }\end{array}$ & year & $\begin{array}{l}\text { Agricultural } \\
\text { Employment } \\
\text { Share (\%) }\end{array}$ & $\begin{array}{c}\text { Industrial } \\
\text { Employment } \\
\text { Share (\%) }\end{array}$ & $\begin{array}{c}\text { Service } \\
\text { Employment } \\
\text { Share (\%) \% }\end{array}$ & $\begin{array}{c}\text { Agricultural } \\
\text { Value Added } \\
\text { of GDP\% }\end{array}$ & $\begin{array}{c}\text { Industrial } \\
\text { Value Added } \\
\text { of GDP\% }\end{array}$ & $\begin{array}{c}\text { Service } \\
\text { Value Added } \\
\text { of GDP }\end{array}$ \\
\hline \multirow{2}{*}{$\begin{array}{l}\text { Latin America and } \\
\text { the Caribbean }\end{array}$} & 1970 & 39 & 22 & 38 & 18 & 33 & 49 \\
\hline & 1990 & 26 & 24 & 5 & 15 & 31 & 5 \\
\hline \multirow[t]{2}{*}{ Asia } & 1970 & 58 & 15 & 26 & 34 & 26 & 40 \\
\hline & 1990 & 40 & 21 & 37 & 20 & 32 & 48 \\
\hline \multirow[t]{2}{*}{ East Asia } & 1970 & 35 & 24 & 38 & 16 & 37 & 46 \\
\hline & 1990 & 19 & 31 & 49 & 6 & 37 & 57 \\
\hline \multirow[t]{2}{*}{ South East Asia } & 1970 & 64 & 11 & 24 & 34 & 25 & 41 \\
\hline & 1990 & 51 & 15 & 32 & 25 & 34 & 41 \\
\hline \multirow[t]{2}{*}{ South Asia } & 1970 & 76 & 9 & 14 & 51 & 16 & 33 \\
\hline & 1990 & 53 & 17 & 25 & 29 & 24 & 47 \\
\hline \multirow[t]{2}{*}{ Sub-Sahara Africa } & 1970 & 78 & 8 & 14 & 35 & 23 & 42 \\
\hline & 1990 & 67 & 11 & 22 & 30 & 26 & 45 \\
\hline
\end{tabular}

Note: Employment shares and values data are from world bank's world development data indicator 1998. Reported figures are five-year averages of underlying annual observation. GDP data from Summers and Heston (1991)

For the developing countries of Middle East and North Africa, a modest upturn in growth in 2010 reflected both an improved external environment and the ongoing effects of earlier stimulus programs.

Higher oil prices in the year benefited developing oil exporters, while rebound in parts of the Euro Area- and growth in high-income Gulf Cooperation Council (GCC) countries helped to support a revival in exports, remittances and tourism. After an advance of $3.3 \%$ in 2010 , the region is expected to enjoy stronger gains of $4.3 \%$ and $4.4 \%$ in 2011 and 2012 respectively, as domestic demand growth continues, export markets firm, and oil prices remain at high levels. The South Asia region is projected to post GDP growth of $7.9 \%$ on average over the 2011- 2012 fiscal years, buoyed by vibrant growth in India.

This compares with estimated growth of $8.7 \%$ in fiscal year 2010. The region benefited from aggressive demand stimulus measures, a revival in investor and consumer sentiment, and a resumption of capital inflows. A recent move toward tighter policy will likely need to be pursued further, given the regions high fiscal deficits (the largest among developing regions), high inflation and deteriorating current accounts.

Output in Sub-Saharan Africa expanded by an estimated $4.7 \%$ in 2010 , a strong rebound following a $1.7 \%$ growth rate in 2009. In South Africa, the region's largest economy, growth at an estimated $2.7 \%$ in 2010 was curtailed by declining private investment, rand appreciation and labour strikes. South African growth is projected to pickup to 3.5\% and $4.1 \%$ in 2011 and 2012 respectively, as global conditions improve further. The rest of the region, excluding South Africa has actually fared better. GDP for these countries expanded an estimated $5.8 \%$ in 2010 and is projected to grow $6.4 \%$ in 2011 and $6.2 \%$ in 2012. The rebound was strongest among the metal and mineral exporters, and oil exporters, which have benefited from stronger commodity prices (World Bank, 2011). 


\section{Contributors to GDP-Regional blocks}

The contributors to GDP in the global economy have been grouped under Agriculture, Industry and Service. Table 4 shows the percentage contribution for the Regional Blocks for 1970 to 1990.

\subsection{Ghana's economic contributors by sectors}

The Table 5 shows the major sectors contributing to Ghana's GDP. For most years the Agricultural sector has been the dominant sector. The real GDP growth has been very slow in the 10 years under review. It recorded the lowest growth of $3.7 \%$ in 2000 and a highest of 7.3 in 2008. The decline in 2009 to $4.1 \%$ is attributed to general downturn in economic fortunes of the rest of the world.

Table 5

Economic growth contributors (GDP)-Ghana 2000 to 2010

\begin{tabular}{rcrrr}
\hline & $\begin{array}{c}\text { Agricultural } \\
\text { Value } \\
\text { Added \% of }\end{array}$ & $\begin{array}{c}\text { Industrial } \\
\text { Value } \\
\text { Added \% of }\end{array}$ & $\begin{array}{c}\text { Service } \\
\text { Value } \\
\text { Added \% of }\end{array}$ & $\begin{array}{l}\text { Total } \\
\text { Real } \\
\text { GDP }\end{array}$ \\
\hline Year & GDP & GDP & GDP \% & Growth\% \\
2000 & 40.0 & 30.0 & 30.0 & 3.7 \\
2001 & 36.0 & 25.0 & 39.0 & 4.2 \\
2002 & 34.4 & 25.9 & 31.0 & 4.5 \\
2003 & 41.4 & 24.0 & 26.7 & 5.2 \\
2004 & 46.7 & 22.1 & 24.3 & 5.8 \\
2005 & 36.0 & 21.5 & 29.9 & 5.8 \\
2006 & 35.4 & 25.9 & 30.0 & 6.0 \\
2007 & 34.7 & 26.0 & 30.6 & 6.3 \\
2008 & 33.6 & 25.9 & 31.2 & 7.3 \\
2009 & 34.5 & 24.9 & 32.3 & 4.1 \\
2010 & 35.6 & 28.3 & 36.1 & 5.9 \\
\hline
\end{tabular}

Source: Ghana Statistical Service, data published by MoFEP, myjoyonline website and 2008 world fact book by CIA

\subsection{Agricultural sector}

From the data above the contributions of the sectors indicate a shift over the 20-year period in the regional blocks. The data shows the agricultural sector's contribution to GDP over the regions has consistently reduced, recording the lowest percentage reduction in sub-Saharan Africa of $14.3 \%$, Latin America and Caribbean, 16.7\%, Asia 41.2\%, Southeast Asia 26.5\% and south Asia 43.1\%. The highest reduction was in East Asia whose value was $62.2 \%$. This is the region where China is located whose contribution plays a major role in the region.
The Chinese economy has shifted way from agriculture to concentrate on other sectors of the economy. The data shows that the service sector was given a major boost. Its contribution to the GDP increased from $46 \%$ in 1970 to $57 \%$ in 1990 . The data available on Ghana also shows a similar trend in the Agricultural sector. However the data over the 10year period shows a lot variation in the trend. Whilst the sector contributed $40 \%$ to the GDP in 2000 the figure had peaked in 2004 to $46.7 \%$ and dropped to $35.6 \%$ in 2010.

The sector has been the backbone of the Ghanaian economy. It has consistently been the major contributor to the country's GDP over the years but has over been taken over by the service sector in 2010, where the service sector recorded $36.1 \%$ as against $35.6 \%$ for Agriculture. Even though the agricultural sector has the contributor to the GDP, the sector is heavily dependent on climatic conditions and governmental policies. Farmers depend on the natural pattern of the rainfall with minimum reliance on irrigation to cultivate their crops. Thus, in a year where the rainfall pattern is hampered, it has a trigger effect on agricultural productivity. Governmental initiatives such as subsidies, research, and available market to producers have not received the needed attention by successive governments.

\subsection{Industrial sector}

With the exception of East Asia, which had an equal contribution of the industrial sector to GDP over the period 1970 to 1990, all the regions improved the sector's contribution. Latin America and the Caribbean however saw a decline from $33 \%$ to $31 \%$. Although the data stresses different causal factors, they reach the common conclusion that economic growth in general, and East Asia's unrivalled growth performance in particular, is not a menopausal phenomenon. Economic growth is affected by many factors, whose cumulative effects can account for much of East Asia's superior performance in relation to that of the world economy as a whole during 1970 90, as well as for the relatively poor performance of South Asia and Sub-Saharan Africa. EastAsia performs better than its measured characteristics would otherwise suggest, whereas South Asia and Africa perform worse. Ghana's industrial sector has had a relative stable contribution to the GDP, recording its highest value of $30 \%$ in 2000 and an average value of $27.9 \%$ over a 10 -year period.

The industrial sector in Ghana has not experience 
the same fortune as the regional blocks compared. Whereas these regional blocks have all shown some amount of growth that of Ghana has remained fairly stable. Even though, Ghana's industrial base is relatively advanced compared to many other African countries. The sector is bedeviled with a host of short falls such as low productivity, competition from cheap and inferior goods from China, high cost of borrowing (currently at 25\%) and in some industries the use of outmoded machinery.

There exists spare capacity for value-added processing of agricultural products. The onset of oil and gas production coupled with the associated industries will significantly improve the sector. The industrial sector in the years ahead is projected to overtake both the Service and Agricultural Sectors in its to the country's GDP.

\subsection{Service sector}

From the regional block data Table 2, the service sector has not shown the kind of trends as in the agricultural and industrial sectors. In the 20-year period, the contribution of the sector to the economy of Latin America and the Caribbean showed a percentage drop of $44 \%$. The sector's contribution to the GDP in 1970 was $49 \%$ dropping to a mere $5 \%$ by 1990. South Asia and East Asia on the other hand experienced immense growth over the period a percentage point of $14 \%$ and $11 \%$ respectively. The literature highlights a wide range of possible explanations for the success of particularly East Asia, including trade and industrial policies, technological progress, savings and capital accumulation, governance, education and health spending, geography and culture, and initial income levels (see, for example, Asian Development Bank 1997; Krugman 1994; Landes 1998; Rodrik 1994, 1998; Sachs and Warner 1995; World Bank 1993; Young 1994, 1995). Southeast Asia showed no growth whereas Sub-Saharan Africa only 3\% increased in the service sector's contribution to the GDP.

As shown in table 5, the service sector has become a major contributor to Ghana's GDP, exceeding the agricultural sector for the first time by $0.5 \%$ points.In 2010, over the 10 year period, the sector's contribution to GDP has remained fairly steady with an average contribution of $28.29 \%$. Like other sectors of the economy, the service sector needs support if it is to continue to be a major contributor to the economy.

Government needs to go into partnership with the private sector to provide the needed investment. Service delivery, application of information
Technology, and provision of state regulatory institutions for effective supervision must all be addressed to make the service sector vibrant.

\subsection{Oil sector contribution to Ghana's growth and the challenges abead}

Ghana inaugurated the commercial production of oil in the last quarter of 2010 after three years of the discovery of the commodity in the Jubilee field in the western coast of the country. By early 2011, it is estimated that Ghana will be producing approximately 120,000 barrels of oil per day. The Jubilee field has 500 million barrels of proven reserves and a potential for over 1 billion barrels. The production rate is expected to supply more than $\$ 400$ million to the government's 2011 budget and around $\$ 1$ billion per year into the country in the early years. Promising indications from adjacent exploration oil wells could mean even higher levels of production and higher revenue from the oil sector into the economy for some years to come.

The oil boom is expected to rain in billions of dollars into the economy. As shown in table 1, the oil sector will help increase the GDP value from $7.0 \%$ to $12.3 \%$ in 2011 . Thus, the sector alone will contribute $43.1 \%$ of the GDP. The start of oil production represents a great opportunity for Ghana to use revenue from the sector to propel other sectors of the economy. Agriculture, which hitherto has been and continue to be the major contributor to the GDP, would need to be mechanised. The researchers view in the management of the oil revenue is to ploy as much as possible into modernising the Agricultural sector. Modernising the sector will have a ripple effect on other GDP contributors to the economy particularly the service and industrial sectors.

The Government and stakeholders in Ghana still have a long way to go if the nations' expectations from the oil sector are not to be curtailed. Underlying challenges need to be addressed as soon as possible. During the field interview, $64 \%$ of the interviewee expressed concern that three-and-a- half years after discovery of the Jubilee field, there is still no oil revenue management law in place and no independent regulatory body has been established for the sector. This is creating a vacuum for the players in the industry. The nation is at present relying on entities engaged in the oil industry themselves to be good cooperate citizens as the nation claws to institute bylaws for the oil sector. The question that needs answering is "can these players be the referee in their own game"? How much will have been lost by the 
time the laws become operational? Government and Parliament need as a matter of urgency to institute laws and a regulatory framework to avert abuse in the oil sector. Again the removal of a ban on using future oil revenues as collateral for loans is particularly worrying. Many oil producers around the world such as Nigeria, Angola and Congo-Brazzaville - have gone deep into debt due to unsustainable oil-backed borrowing. Such loans, with steep interest rates and short repayment terms, are often taken out in secret with little or no parliamentary or public scrutiny.

According to Ian (2010) Ghana has an enviable recent track record of progress on fighting poverty and improving democratic accountability, but the sudden onset of oil wealth often comes at the expense of good governance and effective development. Ghana's challenge as an 'oil hot spot' will be to manage this industry with transparent and accountable policies and practices, so the people of Ghana can truly benefit over the long term.

\section{Conclusions}

The world economy has experience both a doom and burst in the first decade of the millennium. The financial crisis that rocked the world in the latter part of the decade has left governments with no alternative than institute measures to aid economic growth. The trend of the recovery is fast peaking in developing countries than in developed economics with Asian and African countries taking the lead. Ghana, which grew its economy by $6.1 \%$ in 2010 , is projected to grow by $20.14 \%$ (Economic Watch) and by $13.4 \%$ (World Bank) in 2011. With this projected outlook of economic growth in Ghana, the researchers used both qualitative and quantitative data to analyse the factors (agriculture, service and industry) contributing to Ghana's GPD growth and its long-term sustainability. Even though, the agricultural sector has been the main contributor to Ghana's growth over the years the service sector is beginning to overtake it. The industrial sector is still way off and requires investments and advanced technologies. We concluded that, for Ghana to attain and sustain the economic growth, income from the oil sector should be invested in the agricultural sector as the sector employs 40 to $60 \%$ of the working population.

\section{Recommendations}

Ghana's post-independence economic story has been a difficult one, but over the last 20 years, political stability and economic growth has been the long term trend. Ghana is on track to meet the Millennium Development goal of halving extreme poverty by 2015. Real GDP growth averaged $4 \%$ in the mid1980s and has increased to about $5 \%$ over the past decade. Inflation has steadily declined after a rapid increase in 2009. As at the time of the research, inflation had dropped to $8.58 \%$ for December 2010. (News, myjoyonline). The macro-economy remains under pressure from large fiscal and trade deficits. Key economic challenges include: overcoming infrastructure bottlenecks, especially in energy and water; poor management of natural resources; improving human resource capacity and development; establishing a business and investment climate that encourages and allows private sector-led growth, and privatizing remaining state-owned enterprises, several of which are significant budget liabilities. These areas of the economy need not just investment but capacity building and the application of advanced technologies. The country need not start from scratch in their effort to address the issues raised. There abound tried and tested methods from developed and developing economies that can be adopted. The nations need not just be borrowers of the technology but should institute strategies to train its citizens to be innovative and creative in adopting the technologies to suit the country whilst not losing focus on the rest of the world.

On the oil front, Ghana needs to be guided by historical trends in Africa. The exploitation of natural resources in Africa has far too often led to increased poverty and conflict, a phenomenon often referred to as "resource curse." In 2009, Africa produced 13 percent of the world's oil with great investment and exploration throughout the continent, but this has yet to translate into tangible benefits for Africa's poor. In fact, resource-rich countries in Africa have actually experienced lower growth rates than countries with scarce resources.

Ghana is one of the most peaceful and relatively prosperous countries in West Africa but remains poor with the majority of Ghanaians living on less than $\$ 2$ a day. While poverty needs are pressing, stabilization and savings funds must be established and funded to avoid the price shocks and wasteful spending in the early years of an oil boom, which have bedeviled other countries. 


\section{References}

Asian Development Bank., (1997). Emerging Asia. Manila.

Bloom, Canning and Malaney, (1999). Demographic Change and Economic Growth in Asia, CID working paper, vol. 15.

Economic Watch., (2008). China's Economy Forecast, (Online).

Fishlow, A., Gwin, C., Haggard, S. and Wade, R.,eds., Miracle or Design? Lessons from the East Asian Experience. Policy Essay, No. 11., Overseas Development Council, Washington, D.C.

Gary, I., (2010). Ghana's Big Test: Oil's Challenge to Democratic Accountability, Oxfam Report, America, East Asia. Macmillan, London.

Krugman, P. (1994). The Myth of Asia's Miracle. Foreign Affairs, Vol.73,pp. 62-78.

Landes ,D. S., (1999). The Wealth and Poverty of Nations: Why Some Are So Rich and Some So Poor. W. W. Norton, New York.

Rodrik ,D., (1994). King Kong Meets Godzilla: The World Bank and the East Asian Miracle. In Rodrik, D., (1998). TFPG Controversies, Institutions, and Economic Performance in East Asia. In Y. Hayami and M. Aoki, eds., The Institutional Foundation of Economic Development in Rousseau, Peter L. and Sylla, R. (2001). Financial Systems, Economic Growth and Globalisation, National Bureau of Economic Research, Working paper 8323.

Sach, J. D., and Andrew, W., (1997). Sources of Slow Growth in African Economies. Journal of African Economies Vol. 6,pp. 335-76.

Sachs J.D., and Andrew, W., (1995). Economic Reform and the Process of Global Integration. Brookings Papers on Economic Activity, Vol. 1,pp. 1-118.

Summers, R., and Heston, A., (1991). The Penn World Table (Mark 5): An Expanded Set of International Comparisons, 1950-1988. Quarterly Journal of Economics, No. 106,pp. 327-368.

Wang, J., and Jamison, D. T., (1997). Education and Income as Determinants of Fertility: Regional and Temporal Variation in Effects. Unpublished manuscript. World Bank, Washington, D.C.

Webb, S., and Zia, H. , (1990). Lower Birth Rates = Higher Savings in LDCs. Finance and Development No. 27,pp.12-14.
World Bank., (1993). The East Asian Miracle: Economic Growth and Public Policy. Oxford University Press, New York.

World Bank., (2011). World Economic Outlook: Recovery, Risk and Rebalancing. Country and Regional Perspective. (Online).

Young, A., (1994). Lessons from the East Asian NICS: A Contrarian View. European Economic Review, No.38,pp. 964-973.

Young, A., (1995). The Tyranny of Numbers: Confronting the Statistical Realities of the East Asian Growth Experience. The Quarterly Journal of Economics Issue110,No.3, pp.641-80.

Websites:

\section{Economy Watch: World Economy}

http://www.economywatch.com/world_economy/ http://www.economywatch.com/economies-in-top/ http://www.economywatch.com/economicstatictics/gha na/GDPgrowth_constant_prices_national Currency

Germany Economic Stimulus package

http://www.economywatch.com/economystimuluspackage/germany.html

\section{Statistisches Bundesamt Deutschland (Federal Statistical Office-Germany \\ http://www.destatis.de/jetspeed/portal}

Kimberly, A., (2010).US Economic Stimulus Package Available at: http://useconomy.about.com/od/ candidateandtheeconomy/a/obama_stimulus.htm

\section{Congressional Budget Office}

http://useconomy.about.com/od/governmentagencies/p /CBO.htm

\section{Office for National Statistics-UK}

http://www.statistics.gov.uk/hub/economy/index.html http://www.statistics.gov.uk/cci/nugget.asp? $\mathrm{id}=192$

\section{Ghana Economy: 2010 CIA WORLD FACTBOOKAND OTHER SOURCES}

http://www.theodora.com/wfbcurrent/ghana/ghana_ec onomy.html

Ghana Statistical Service: Budget Statements

http://Statsghana.gov.gh/keysocial.html

Ghana Budget Statement 2000 to 2006

http://www.ghanaweb.com/ghanaHomepage/economy/ budget.php

\section{Ministry of Finance and Economic Planning} http://www.ghanareview.com/directory/2009BUDGET .pdf. 